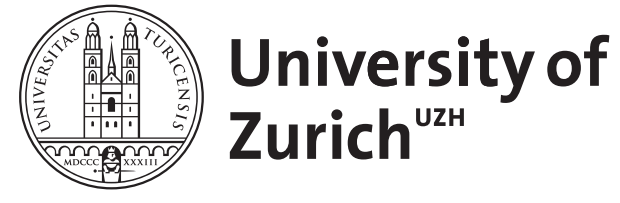

Zurich Open Repository and Archive

University of Zurich

University Library

Strickhofstrasse 39

CH-8057 Zurich

www.zora.uzh.ch

Year: 2000

On the syntax of agreement in Tibeto-Burman

Bickel, Balthasar

DOI: https://doi.org/10.1075/sl.24.3.05bic

Posted at the Zurich Open Repository and Archive, University of Zurich

ZORA URL: https://doi.org/10.5167/uzh-76615

Journal Article

Originally published at:

Bickel, Balthasar (2000). On the syntax of agreement in Tibeto-Burman. Studies in Language, 24:583609.

DOI: https://doi.org/10.1075/sl.24.3.05bic 


\title{
ON THE SYNTAX OF AGREEMENT IN TIBETO-BURMAN
}

\author{
Balthasar Bickel \\ University of California at Berkeley and University of Zürich
}

\begin{abstract}
Verb agreement in Tibeto-Burman languages follows a different principle than in other, especially Indo-European languages. Instead of limiting agreement to the unification of features of the agreement trigger with those of the target, TibetoBurman languages also allow NP features to combine with the features marked by the agreement morphology in an appositional ('as NP'), partitional ('NP of') or relational ('NP with regard to') structure. This possibility is shown to result from an associative principle in the syntax-semantics interface underlying Tibeto-Burman, and more generally Sino-Tibetan grammar, which is distinct from the more integrative design of Indo-European languages. These differences also manifest themselves in grammatical relations structure, role semantics, and discourse tendencies.
\end{abstract}

\section{Introduction}

Some languages of Tibeto-Burman stock, notably those classified as Kiranti, Kuki-Chin and Qiangic, show systems of verb agreement. In this paper I examine the nature of such systems and their syntactic structure. For agreement by no means universally consists of a simple 'unification' or 'matching' of the features of an agreement trigger with those of its target. There is indeed a variety of ways in which agreement features can be combined, and languages vary in this regard in principled ways (1999b, c, d). Even more than research on grammatical relations, the study of agreement systems has suffered from a heavy bias toward European languages. A notable exception to this is Hale (1983), who distinguishes between a 'merged' and an 'unmerged' (i.e. co-predicative or appositional) relationship between NPs and agreement clitics in the Australian language Warlpiri. In fact, there are more possibilities, and they characterize agreement throughout 
Tibeto-Burman. I discuss these possibilities in Section 2, concentrating on two languages to which I have first-hand access through fieldwork or other native speaker consultations, and which are generally assumed to be related only distantly (Matisoff 1991): Belhare, a representative of the Kiranti group spoken in Eastern Nepal, and Lai Chin, a representative of the Kuki-Chin group spoken in Western Burma (Myanmar) and adjacent parts of Bangladesh. In Section 3, I compare variable agreement relations with at first sight similar phenomena in Indo-European languages, drawing a distinction between associative and integrative agreement systems. Section 4 relates this distinction to other typological features in semantics, syntax, and discourse. In all of these domains, languages with associative agreement show a greater separation of the nominal and the verbal encoding of arguments than languages with integrative agreement. This difference reflects a general choice in grammar principles that go beyond the mechanisms of agreement. There is evidence that a principle of associative grammar is also characteristic of those Tibeto-Burman languages that do not have agreement, and indeed extends throughout the Sino-Tibetan family. Section 5 summarizes these findings, and proposes that the principle of associative grammar can be consistent in a language family even if the family is heterogenous in the development of agreement morphology, as is the case of Sino-Tibetan.

\section{Agreement relations in Tibeto-Burman}

Table 1 gives a synopsis of the various agreement relations attested in Tibeto-Burman. Identificational corresponds to Hale's (1983) terms 'merged' (or 'argumental'), appositional to 'unmerged' (or 'predicative'). ' $\mathrm{F}_{\mathrm{N}}$ ' and ' $\mathrm{F}_{\mathrm{V}}$ ' stands for referential features marked by nominals and verbal agreement markers, respectively.

Table 1. Agreement relations in Tibeto-Burman

\begin{tabular}{ll}
\hline $\mathrm{F}_{\mathrm{N}}=\mathrm{F}_{\mathrm{V}}$ & identificational \\
$\mathrm{F}_{\mathrm{V}}$ as $\mathrm{F}_{\mathrm{N}}$ & appositional ('as NP') \\
$\mathrm{F}_{\mathrm{N}}$ of $\mathrm{F}_{\mathrm{V}}$ & partitional ('NP of') \\
$\mathrm{F}_{\mathrm{N}}$ re $\mathrm{F}_{\mathrm{V}}$ & relational ('NP with regard to')
\end{tabular}


Three of these possibilities are illustrated by examples from Belhare: the examples in (1) show identificational agreement, i.e. what corresponds to garden variety agreement in Indo-European. ${ }^{1}$

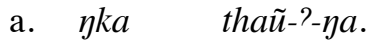
1SG[ABS] go.up-NON.PAST-[1SG:S]EXCL
'I'll go up.'
b. han i-na rig sa-a
2SG[ABS] DISTR-DEM story[ABS] who[SG]-ERG
n-lur-he-ga?
3[SG]A-tell-PAST-2[SG:UND]
'Who told you that story?'

The following set of examples illustrates appositional agreement, where the NP that bears the same thematic role as the agreement marker functions semantically as an apposition to this marker. The nominal features do not merge into a single referential expression with the conjugational desinence but instead predicate additional information about the referent. Therefore, there is no need for there to be a 1:1 matching between person features on the verb and those of the NP it agrees with:
a. na-kha-ek-kha
DEM-NON.SG-LOC-NMLZR
ka-y-piu-?-ni.
[1 PL]INCL:UND-3NON.SG:A-give-NON.PAST-NEG
'They don't give seats to us ${ }^{\text {INCL }}$ from here (only to long- distance passengers.)'
(literally, 'they-don't-give-us locals')

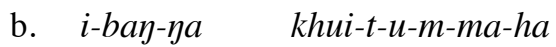 one-HUM-ERG carry-NON.PAST-3[SG]UND-1 PL:A-EXCL-NMLZR '[It's] one that we ${ }^{\mathrm{INCL}}$ can carry alone.' (literally, 'we-can-carry-it [as] one-person')
c. sıp may khim-chi-a ak-chitt-u-m. all god house-NON.SG-ERG OPT-get-3[SG]UND-1PL:A 'We $\mathrm{I}^{\mathrm{INCL}}$ should get [money] through all god-houses.' (literally, 'we-get-it all [as] god-house-units') 
d. daju-bhai mun-dhupt-a-chi!

EBro-Ybro[sG:ABS] talk-IMP-[2]DUAL[S]

'Talk to each other as brothers!'

(literally, 'you-talk [as] brothers!')

e. masin=cha siy tayn-e

old.woman[SG.ABS]=even wood plant-LOC

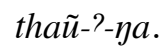

climb-NON.PAST-[1SG]EXCL

'Even as an old woman I climb trees.'

(literally, 'even [as] old-woman I-climb on-trees')

The following examples, finally, illustrate 'partitional' agreement, where the NP denotes a subset of the referents denoted by the agreement marker. In this case, number features systematically disagree:
a. sip-pay bıjar khar-e-i-ya.
two-HUM bazaar[LOC] go-PAST-1PL[S]-EXCL
'Two of us ${ }^{\mathrm{EXCL}}$ went to the bazaar.'
(literally, 'two we-go to the bazaar')
b. na kasıi-ya hit-ma
DEM[SG:ABS] who:EMPH[SG]-ERG see-INF
$m i-n-t o u-t-u-n$.

3NON.SG[A]-NEG-can-NON.PAST-3[SG]UND-NEG

'Not one of them gets to see her.'

(literally, 'whoever they-don't-see-her')

c. $s a-t i \quad k h a r-e-i-g a$ ?

who-SG:ABS go-PAST-2PL[s]-2

'Who of you went?'

(literally, 'who you-go?')

d. i-bay pok-kheys-e-i-ga ki

one-HUM[ABS] rise-DIM-PAST-2PL[S]-2 SEQ

up-yuk-na.

beat.up-DEF-1[SG:A]>2[SG:UND]

'If any of you ${ }^{\mathrm{PL}}$ rises a bit, I will beat him (lit., you ${ }^{\mathrm{SG}}$ ) up.' (literally, 'one-person you-rise-a-bit, and-then I-beat-you')

e. sum-bay u-tak-chi

three-HUM 3[SG]POSs-friend-NON.SG[ABS] 
n-ta-he pheri i-na

3NON.SG[S]-come-PAST and.then DISTR-DEM[SG:ABS]

i-bay-na m-phou-t-u,

one-HUM-ERG 3NON.SG[A]-help-NON.PAST-3[SG]UND

sru-ya ambi=bu $i$ yeti $i$

other-ERG mango[ABS]=REP Q what[ABS] Q

y-kop-yuk-t-u.

3NON.SG[A]-pick.up-keep.for-NON.PAST-3[SG]UND

'Three of his friends came. Then one of them helps him [get up], the others pick the mangoes or what and keep them for him.'

(literally, 'one-person they-help-him')

The same variety of agreement relations is found in Lai Chin. The set of examples in (4) illustrates identificational agreement, the one in (5) appositional agreement, and the one in (6) partitional agreement: ${ }^{2}$

(4)

a. $a-m a^{2} \quad a-n i$.

$3[\mathrm{SG}]-\mathrm{DEM}[\mathrm{ABS}] 3[\mathrm{SG}] \mathrm{S}-$ laugh: $\Sigma 1$

'S/he laughs.'

b. Tsew Máy ni' làw thlàw po:l a-perk-naar.

T. ERG farmer PL[ABS] 3[SG]A-give: 2 2-3PL:UND

'Tsewmang gave it to the farmers.'

(5)

a. tsó:n piaktu: ni? làw

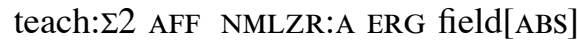

ka-thlo? vér.

1[SG]A[-3SG:UND]-work: 2 even

'Even as a teacher I can work the field.'

b. làw kál láw tsùr zày tin da? mir nùy fa:

field go: 2 NEG TOP what do Q person alive son[ABS]

kà-n-’um tsork lary?

1-PL:S-exist: $\Sigma 1$ all FUT

'As the sons of humans, how can we manage (literally, 'how can we at all exist') without going to the field?'

(6)

a. a-háw da? nà-n-rar?

3[SG]-who[ABS] Q 2-PL:S-come: 1

'Who of you came?' 


\section{b. mìr pa-khat (loy) kà-n-raí. \\ person CLASS-one[ABS] only 1-PL:S-come: $\Sigma 1$ \\ '(Only) one of us came.'}

Lai Chin, however, carries this further than Belhare and also uses nonidentificational agreement as a primary coding means in experience expressions. Such expressions follow the general South East Asian model of psycho-collocations (Matisoff 1986). The experiencer is expressed by a possessor prefix on the experiential noun (see Van-Bik 1998 for the semantic range of this construction):

$$
\begin{aligned}
& \text { ka-lùy a-rìn. } \\
& \text { 1[SG]POSS-heart[ABS] 3[SG]S-suspicious: } \Sigma 1 \text { (lit., 'green') } \\
& \text { 'I am suspicious.' (literally, 'my-heart is-suspicious') }
\end{aligned}
$$

If there is also a specific stimulus argument involved, this is coded by means of a regular intransitive agreement marker:

$$
\begin{aligned}
& \text { a. (này-ma?) ka-lùy na-rì̀. } \\
& \text { 2SG-DEM[ABS] 1[SG]POSS-heart[ABS] 2[SG]S-suspicious: } \Sigma 1 \\
& \text { 'I suspect you.' } \\
& \text { (literally, 'my-heart }\left[\mathrm{F}_{\mathrm{N}}\right] \text { re you }\left[\mathrm{F}_{\mathrm{V}}\right] \text {-suspicious') } \\
& \text { b. (à-n-ma?) ka-lùy à-n-rìn. } \\
& \text { 3-PL-DEM[ABS] 1[SG]POSS-heart[ABS] 3-PL[S]-suspicious: } 1 \\
& \text { 'I suspect them.' } \\
& \text { (literally, 'my-heart }\left[\mathrm{F}_{\mathrm{N}}\right] \text { re them }\left[\mathrm{F}_{\mathrm{V}}\right] \text {-suspicious') }
\end{aligned}
$$

Although from an Indo-European point of view one is tempted to understand such constructions as 'you/they [make] my heart suspicious', the Lai verb is clearly intransitive. The structure here is different. The verb is predicated of kaluy 'my heart' (it is, after all, the first person referent that is suspicious in the example), but it does not agree syntactically with this NP nor with its possessor. Instead, the agreement prefix indexes the person with regard to whom the psycho-collocation holds, i.e. the stimulus nayma' 'you' (8a) or anma' 'they' (8b), respectively. Thus, a better approximation of the semantic structure of (8) is 'my-heart with regard-to-you/them ${ }_{i}$ you/they ${ }_{i}$-are-suspicious', where agreement consists in establishing a relation ('with regard to', ' $r e$ ') between the features $\mathrm{F}_{\mathrm{N}}$ of the psycho-noun (kaluy 'my-heart') and the verbal features $\mathrm{F}_{\mathrm{V}}$ encoded by the conjugational prefixes ( $\mathrm{na}$ - 'you' and an'they', respectively). Proof for the intransitive nature of the verb in (8) comes 
from the fact that it cannot appear in what has come to be called the second stem (rin) and that ergative case on the stimulus NP is ungrammatical:
a. *(à-n-ma?) ka-lùy
3-PL-DEM 1[SG]POSS-heart[ABS]
à-n-rín.
3-PL:A-[3SG:UND]-suspicious: 22
b. *à-n-ma? ni? ka-lùy
3-PL-DEM ERG 1[SG]POSS-heart[ABS]
à-n-rín.
3-PL:A-[3SG:UND]-suspicious: 22
c. *à-n-ma? ni? ka-lùy
3-PL-DEM ERG 1[SG]POSS-heart[ABS]
a-n-rín.
3-PL:A-[3SG:UND]-suspicious: 21
Intended: 'I suspect them'

Both options are possible only in truly transitive constructions. Such constructions do exist as versions of (8), but they involve explicit, derivational transitivization, marked either by glottalization ( $<$ Proto-Tibeto-Burman 'directive' *-t) or the causative particle ter (see Peterson 1998; Van-Bik 1999):

a. (à-n-ma? ni?) ka-lù

3-PL-DEM ERG 1[SG]POSS-heart[ABS]

à-n-ka-rìn.

3-PL:A-1[SG]UND-suspicious: 2 :CAUS

'[They behave as if they wanted to make] me suspicious of them.'

b. (⿳亠口冋-n-ma? ni’) ka-lùy

3-PL-DEM ERG 1[SG]POSS-heart[ABS]

àn-ka-rín tèr.

3-PL:A-1 SG:UND-suspicious: 2 CAUS

'They made me suspicious [of them].'

(literally, 'they cause my heart to be suspicious')

In these examples, the undergoer agreement marker $k a$ - 'me' registers the possessor of the experience ( $k a$ - 'my') following a pattern of external possessor (dativus possessivus) coding that is characteristic throughout Tibeto-Burman (van Driem 1991). ${ }^{3}$ Another example with external possessor 
agreement is (11a), an alternative to (11b):

$$
\begin{aligned}
& \text { a. (ka-)tsa: uk a-ka-fiár. } \\
& \text { 1[SG]POSS-book[ABS] 3[SG]A-1[SG]UND-steal: } \Sigma 2 \\
& \text { 'S/he robbed me of my book.' } \\
& \text { b. ka-tsa: uk a-fiár. } \\
& \text { 1[SG]POSS-book[ABS] 3[SG]A[-3SG:UND]-steal: } 22 \\
& \text { 'S/he stole my book.' }
\end{aligned}
$$

External possessor marking is standard identificational agreement, but the relevant features come from a dependent (the possessor $k a$ - 'my') of the agreement-triggering NP rather than from its head (tsa: $u k$ 'book'). The general rule behind it is that an affected possessor can take precedence over its host in providing agreement features - a wide-spread phenomenon in the world's languages (cf., e.g. Bally 1926; Shibatani 1994; König and Haspelmath 1998; Payne \& Barshi 1999). However, just as the subject agreement marker can signal relational rather than identificational agreement, so can the undergoer marker index the stimulus to which the psycho-noun is related, instead of this nominal itself. This is the case in examples like the following, where the semantics is self-causative and conversationally implicates that 'they start to suspect me on their own initiative, without having any good reason' (Kenneth Van-Bik, p.c.):

$$
\begin{aligned}
& \text { à-n-lùy } \quad \grave{a}-n-k a-r i{ }^{i} n \text {. } \\
& \text { 3[PL]POSS-heart[ABS] 3-PL:A-1[SG]UND-suspicious: 22:CAUS } \\
& \text { 'They [are ready to] suspect me.' } \\
& \text { (literally, 'they }\left[\mathrm{F}_{\mathrm{V}(\mathrm{A})}\right] \text {-cause their-heart }\left[\mathrm{F}_{\mathrm{N}}\right] \text { re me }\left[\mathrm{F}_{\mathrm{V}(\mathrm{U})}\right] \text { - }
\end{aligned}
$$

The effect of this is that the same verb form, ankari'n, can have opposite meanings: combined with kaluy 'my heart' in (10) it entails 'I suspect them'; in (12), with anluy 'their heart', it entails 'they suspect me'. In these examples, the form is disambiguated by the possessor prefix ka- 'my' vs. an- 'their' on the noun. However, if stimulus and experiencer have the same person and number features, ambiguity can arise between identificational and relational agreement (third person singular undergoer agreement is zero-marked): 
(13)

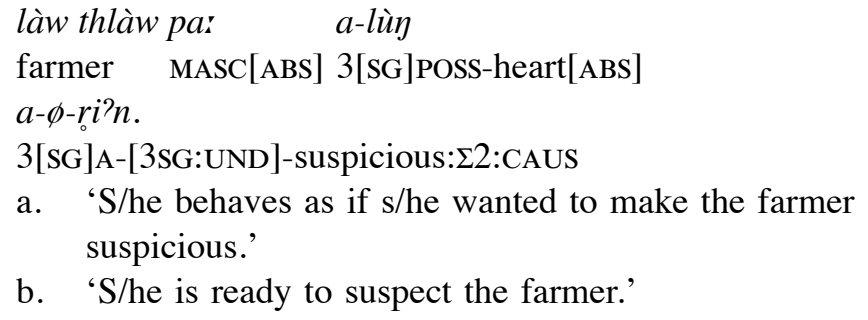

b. ' $\mathrm{S} / \mathrm{he}$ is ready to suspect the farmer.'

In the first interpretation, undergoer agreement is identificational and is with the experiencer/possessor $(a-)$ in the style of an external possessor construction. The second interpretation rests on relational agreement, where the undergoer marked on the verb registers the stimulus (law thlaw pa: 'farmer') with regard to whom 'his/her heart is suspicious'.

A similar ambiguity arises in intransitive constructions of the type illustrated before in (7) and (8). This is shown in the following example noted by Van-Bik (1998: 203):
(14) ka-lùr $a$-rí:.
1 [SG]POSS-head[ABS] 3[SG]S-confused: $\Sigma 1$ (lit. 'drunk: $\Sigma 1$ ')
a. 'I am confused.'
b. 'He made me confused.' (literally, 'I am confused because of him.')

In (14a), agreement is taken to be identificational, whence the third person features merge with those of the subject NP kalu: 'my head'. In (14b), agreement is understood as relational so that the verbal prefix $(a-)$ denotes the stimulus argument.

These ambiguities are unexplained unless we recognize the difference between identificational and relational agreement.

\section{Associative vs. integrative agreement}

At first sight one might take the examples of non-identificational agreement discussed in the preceding for simple cases of agreement mismatches of the kind that is common in many Indo-European languages (e.g. Corbett 1983). However, disagreement in Indo-European is usually not exploited as a constructional resource. Instead, it commonly has to do with variation in the semantic construal of features in the NP and in the conjugational system. 
In a case like English the government is/are ..., for example, the relation between the NP and the conjugational system is still one of identity: the variation results from whether or not government is taken to be a singular or a plural noun. Another source for variation arises from the way features are inherited in phrase structures. Consider the following data from English and Nepali (Indo-Aryan):

(15) a. One of the boys are/is working on this.

b. (hämiharu madhye) ek jana $1 \mathrm{PL} \quad$ among one person[NOM] āu-nch-aũ / äu-nch-a. come-NON.PAST-1PL come-NON.PAST-3SG

'One of us will come.'

(16) a. *Of us, one are working on this.

b. *ek jana āu-nch-aũ, hāmiharu madhye. one person[NOM] come-NON.PAST-1PL 1PL among 'One of us will come.'

Plural marking in (15) is reminiscent of the Belhare and Lai Chin partitional constructions. However, for the English and Nepali constructions it is essential that one and ek jana are the heads of complex NPs containing the PPs of the boys and hämiharu madhye 'among us', respectively - even if the PP is suppressed through ellipsis as is possible in Nepali (but not in English). It is these PPs that contain the agreement features reflected in the verb (as third person plural in (15a) and as first person plural (15b)). This is why plural agreement is blocked if the PPs are moved out of the NPs into a detached position, as shown in (16). This suggests that first person plural agreement in (15) results simply from 'piping' the relevant features from the PP to the NP-head, or in the absence of an overt PP, from conceptually construing the notion of 'of us' or 'among us' within the NP (constructio ad sensum). This is different in the Tibeto-Burman constructions. Where an adverbial expression like the PPs in (15) is at all available, it does not form a subconstituent of the agreement-triggering NP. Hence, placing kankhua in 'from our village' in the following Lai Chin example into the afterthought or any other position does not interfere in any way with the agreement system: 
a. kà-n-khùa in mì̀ pa-khat 1-PL:POSS-village from person CLASS-one[ABS]

kà-n-ra:.

1-PL:S-come: $\Sigma 1$

'One from our village came.'

b. mì̀ pa-khat kà-n-rar, person CLASS-One[ABS] 1-PL:S-come: $\Sigma 1$

kà-n-khùa in.

1-PL:POSS-village from

'One came, one from our village.'

c. mì̀ pa-khat kà-n-khùa in

person CLASS-one[ABS] 1-PL:POSS-village from

$k a ̀-n-r a:$.

1-PL:S-come: $\Sigma 1$

'One from our village came.'

Often, however, such PPs are not even available: in neither Belhare nor Lai Chin are there adpositions like English as that would mark appositional readings. Moreover, as we saw in the Lai Chin experiencer construction in (8), lexical expression of the stimulus argument results in a free absolutive NP rather than in a subconstituent of kaluy 'my heart'. As shown by the following, the stimulus NP can appear anywhere in the clause, in synchrony with the contextually appropriate information structure:

a. nikúm a? [ ${ }_{\mathrm{NP}}$ làw thlàw po:l $]$

last.year LOC farmer PL[ABS]

[NP ka-lùn] à-n-rì̀.

1[SG]POSS-heart[ABS] 3-PL:S-suspicious: $\Sigma 1$

'Last year I suspected the farmers.'

b. [ [NP làw thlàw po:l $] \quad$ nikúm a?

farmer $\quad \mathrm{PL}[\mathrm{ABS}]$ last.year LOC

[NP ka-lùy] à-n-rì̀

1[SG]POSS-heart[ABS] 3-PL:S-suspicious: $\Sigma 1$

'The farmers, I suspected them last year.'

This is different with true NP subconstituents which cannot be separated from their heads: 
(19)

$$
\begin{aligned}
& \text { a. nikúm a? [ } \text { [NP } \text { ka-hòry khña] } \\
& \text { last.year LOC 1[SG]POSs-friend village[ABS] } \\
& \text { ka-mu? } \\
& \text { 1[SG]A[-3sG:UND]-see: } \Sigma 2 \\
& \text { 'Last year I saw my friend's village.' } \\
& \text { b. *[ } \left.\left.{ }_{\mathrm{NP}} k a-h o ̀ r y\right] \quad \text { nikúm a? }{ }^{\text {[N }} \text { khùa }\right] \\
& 1 \text { [SG]POSS-friend last.year LOC village[ABS] } \\
& \text { ka-m̊u? } \\
& \text { 1[SG]A[-3SG:UND]-see: } 22 \\
& \text { 'I saw my friend's village last year.' }
\end{aligned}
$$

Some cases of agreement mismatches in Indo-European languages have been compared to the kind of appositional ('unmerged') structures found in Australian languages (Jelinek 1984) and could thus also be compared to what we find in Tibeto-Burman. Consider the following examples from Spanish:

$$
\begin{aligned}
& \text { a. Los español-es bebe-mos mucha } \\
& \text { ART:PL:MASC spaniard(MASC)-PL drink-1PL:PRES much } \\
& \text { cerveza. } \\
& \text { beer } \\
& \text { 'We Spaniards drink a lot of beer.' } \\
& \text { b. Los español-es bebé-is mucha } \\
& \text { ART:PL:MASC spaniard(MASC)-PL drink-2PL:PRES much } \\
& \text { cerveza. } \\
& \text { beer } \\
& \text { 'You Spaniards drink a lot of beer.' }
\end{aligned}
$$

However, rather than representing true appositional agreement, this pattern is more likely to result from ellipsis of the agreement-triggering pronouns nosotros 'we' and vosotros 'you (PL)', respectively, which are much longer and prosodically heavier than their monosyllabic counterparts in the singular $(y o, t u)$. This explains why disagreement is impossible with other person and number values in Spanish (21a). Also note that the pattern does not extend to partitional interpretations and is therefore incompatible, for instance, with question words (21b):

$$
\text { a. *El español beb-o muchacerveza. }
$$

ART:SG:MASC spaniard drink-1SG:PRES much beer 'As a Spaniard I drink a lot of beer.' 


\section{b. * ¿Quién bebéis cerveza? who:SG drink-2PL:PRES beer \\ 'Who of you drinks beer?'}

As illustrated by the examples in the preceding section, there is usually no such constraint in Tibeto-Burman languages. A final Indo-European pattern that might constitute a prima facie parallel to the Tibeto-Burman agreement varieties comes from Maithili, an Indo-Aryan language spoken in the India state of Bihar and adjacent areas of Nepal. This language has a secondary set of non-nominative agreement markers which can register referents related to an NP (Yadava 1996; Bickel, Bisang and Yadava 1999). At first sight this could be thought of as relational agreement of the kind illustrated by Lai Chin in the preceding section:

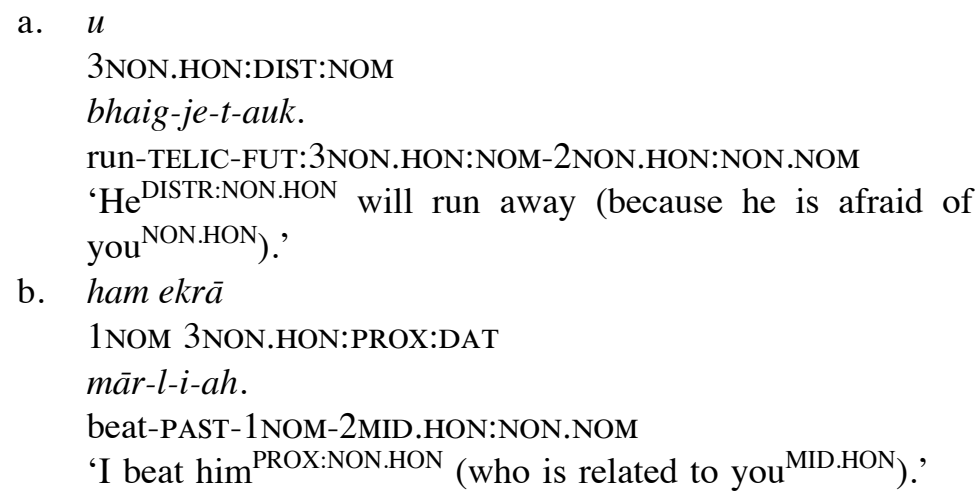

However, unlike in true relational agreement, the person inflection in (22) does not substitute for identificational agreement but instead introduces an additional, extra-thematic argument. ${ }^{4}$ This is similar to identificational agreement along the lines of affected possessor agreement that was illustrated by the Lai Chin examples in (10) and (11). ${ }^{5}$ Confirmation of this comes from the fact that agreement as in (22) is possible only with datives or other obliques. It is incompatible with the nominative type of agreement markers which is reserved for standard subject agreement:

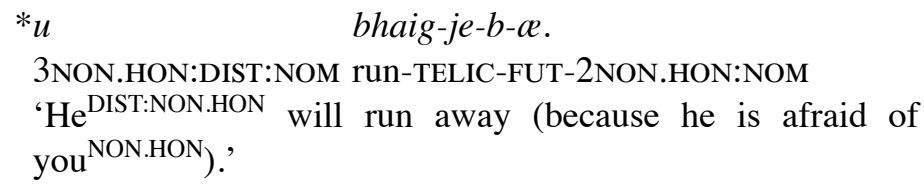


In summary, while Indo-European languages often allow some variation in feature construal and inheritance as well as in ellipsis and argument addition, they do not seem to systematically exploit disagreement as a constructional resource in the way that is common throughout those TibetoBurman languages that have agreement systems. I propose the notion of associative agreement to terminologically fix this constructional resource; it contrasts with the integrative agreement typically found in Indo-European, where agreement triggers and targets are integrated with each other into a unified referential expression. It is important to notice that both associative and integrative agreement are grammatically constrained systems, but they are constrained in different ways. In integrative agreement, the basic condition that must be observed is that features are identified at some point and create one single referential expression. Individual languages may impose additional constraints on feature inheritance and construal, e.g. disallowing, as German does, plural agreement of the kind illustrated by (15a) in English. In associative systems, the combination of features must comply with the types of agreement relations that a specific construction allows, and this varies across languages. The relational type found in Lai Chin experience constructions, for instance, is not attested in Belhare. In addition to this, associative agreement can impose, just like integrative systems, additional language-specific constraints. In Belhare, for example, partitional agreement is possible only with human referents (24a). With nonhuman referents (24b) one has to resort to a circumlocution (24c).

$$
\begin{aligned}
& \text { a. i-bay } \quad \eta y \text {-att-he. } \\
& \text { one-HUM[ABS] 3NON.SG[s]-visible-PAST } \\
& \text { 'One could see one of them (people).' } \\
& \text { b. *i-gira } \quad \eta \eta \text {-att-he. } \\
& \text { one-NON.HUM[ABS] 3NON.SG[s]-visible-PAST } \\
& \text { 'One could see one of them (e.g. monkeys, houses etc.).' } \\
& \text { c. sıppe } \eta \eta \text {-atd-at-ni, } \\
& \text { all[ABS] 3NON.SG:S-visible-PAST-NEG } \\
& \text { i-gira=etlo att-he. } \\
& \text { one-NON.HUM[ABS]=only [3SG:S-]visible-PAST } \\
& \text { 'One couldn't see all. Only one was visible.' }
\end{aligned}
$$

Such a constraint reflects the low attention Belhare grammar affords to nonhuman referents - a phenomenon that is typologically comparable to cases 
in integrative agreement system where human, or more generally animate NPs are better triggers of (identificational) agreement than inanimate NPs (as, e.g., in Russian dialects; see Corbett 1983: 110-11).

\section{Toward a typological explanation}

In one respect, the distinction between integrative and associative agreement seems to parallel the one drawn by Bresnan and Mchombo (1987) between grammatical and anaphoric agreement: the compositional nature of associative agreement suggests that the agreement markers have a referential function independent of their associated NPs, and this is also characteristic of anaphoric agreement. However, anaphoric agreement in Bresnan and Mchombo's sense is incompatible with overt NPs in argument positions since the agreement markers absorb such positions in the syntactic structure of the clause. This is not so in associative agreement systems. As we saw in many examples in the preceding sections, associative agreement is fully compatible with overt NPs in argument position. Unlike what Bresnan and Mchombo find in the Bantu language Chichewa, there is no phrase-structural constraint against the appearance of overt argumental NPs in Belhare or Lai Chin clauses. For instance, word order possibilities in Belhare are entirely independent of whether or not there is object agreement:

a. na-kha-ya ina

DEM-NON.SG-ERG beer[ABS]

n-thuu-t-u .

3NON.SG[A]-cook-NON.PAST-3[SG]UND

'These [people] make the beer (i.e. this specific beer here).'

b. ina na-kha-na

beer[ABS] DEM-NON.SG-ERG

$n$-thuu-t-u .

3NON.SG[A]-cook-NON.PAST-3[SG]UND

'The beer is made by these [people].'

a. na-kha

ina

n-thuk-yu.

DEM-NON.SG[ABS] beer[ABS] 3NON.SG[S]-cook-NON.PAST

'These [people] make beer.' 


\section{b. ina na-kha n-thuk-yu. \\ beer[ABS] DEM-NON.SG[ABS] 3NON.SG[S]-cook-NON.PAST \\ 'Beer is made by these [people].'}

The presence of object agreement implies referentiality, its absence a generic use of the object NP. This semantic distinction has no consequence for the phrase structure, which exclusively reflects information structure (see Bickel, in press, for discussion).

While associative agreement can create an appositional semantics, the NPs are not eo ipso syntactically relegated to the position of an adjunct or an apposition in the way that is typical for many strictly head-marking languages (cf., apart from Bresnan and Mchombo 1987; DuPonceau 1819; von Humboldt 1836; Van Valin 1985; Mithun 1985; Baker 1996; and many others). ${ }^{6}$ This is confirmed by the following observation. One common characteristic of adjunct positions is that they form islands for extractions (cf., e.g. Chung 1998: 85). In line with this, it is impossible in Belhare to extract a constituent out of an adjunct (27). By contrast, extraction out of a subject NP is perfectly possible (28):
a. [a-tak-yaha
u-khimm-e]
b. *[u-khimm-e $]$
n-tupt-he,
'They met at my friend's place.'

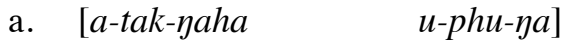
1 [SG]POSS-friend-GEN 3[SG]POSS-E.Bro-ERG
mai-lur-he.
1SG:UND-[3SG:A-]tell-PAST
b. $\quad[u-p h u-\eta a] \quad$ mai-lur-he,
$3[$ SG]POSS-E.Bro-ERG 1 SG:U-[3SG:A-]tell-PAST
[a-tak-yaha]
1 [SG]POSS-friend-GEN
'My friend's elder brother told me.'

n-tupt-he.

1SG:POSS-friend-GEN 3sG:POSS-house-LOC 3PL[s]-meet-PAST

[a-tak-yaha]

3sG:POSS-house-LOC 3PL[s]-meet-PAST 1sG:POSS-friend-GEN

(28)

Associative agreement is therefore fully compatible with NPs in core argument positions. This suggests that the nonidentificational possibilities offered by such systems is not a typological concomitant of having argument positions absorbed by agreement markers, as is sometimes claimed in discussions of Australian languages (e.g. by Jelinek 1984 or Pensalfini, in press). 
At least in Tibeto-Burman languages, the typological source is different. ${ }^{7}$ It is tied to a systematically loosened syntactic connection between semantic information represented by NPs on the clause level and semantic information contained in the predicate.

In Bickel (1999b,c,d) a fundamental typological distinction is proposed between the ways in which the interface between syntax and semantic is designed. In languages with an integrative interface, clause- and predicatelevel information is simultaneously relevant for the definition of syntactic constraints. Applied to agreement systems, such constraints have the effect that referential features represented on the clause level, i.e. by NPs, are inherently tied to the features represented by the verbal agreement markers and must merge with them into a single unified set. Tibeto-Burman languages have an associative interface design, where clause-level information and predicate-level information are kept separate from each other. In agreement systems, referential features are therefore coded on NPs and verbs separately and are then linked together through the interpretational machinery of associative agreement. An associative syntax-semantics interface implies a general tendency to keep the nominal and the verbal encoding of argument roles separate from each other throughout the grammar. Such a tendency manifests itself in semantics, syntax, and discourse.

In semantics, the associative design principle has the effect that the semantic role structure of verbs is often distinct from that found in the casemarking system. In Belhare, for instance, the transitive actor (A) role of many verbs can be occupied by animate referents only $(29 a, b)$. The nominal A marker, i.e. the ergative case, by contrast, covers animate as well as inanimate referents $(29 b, c)$ :

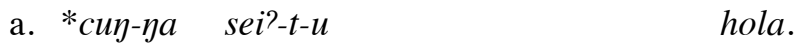

$$
\begin{aligned}
& \text { cold-ERG [3SG:A-]kill-NON.PAST-3[SG]UND probably } \\
& \text { 'The cold will probably kill him/her.' } \\
& \text { b. a-tak-ya sei?-t-u } \\
& \text { 1[SG]POSS-friend-ERG [3SG:A-]kill-NON.PAST-3[SG]UND } \\
& \text { hola. } \\
& \text { probably } \\
& \text { 'My friend will probably kill [the chicken].' } \\
& \text { c. сил-ya si-yu hola. } \\
& \text { cold-ERG [3sG:S-]die-NON.PAST probably } \\
& \text { 'He will probably die from the cold.' }
\end{aligned}
$$


Accordingly, if a sentence like the following has a transitive verb form of such a lexeme, the inanimate ergative NP must be understood as instrumental and cannot be taken to fulfill the agentive role:

$$
\text { luyghek-ya sisa her-e. }
$$

stone-ERG glass(window)[ABS] [3SG:A-]break-PAST[3SG:UND]

'Somebody broke the window with a stone.'

Not: 'The stone broke the window.'

Such differences between case and agreement semantics are usually not found in Indo-European languages, at least not in their most prominent case, i.e. the nominative.

Relational syntax too keeps NP and verb structure strictly apart. Belhare has one type of experience expression which is modeled after the pan-IndoEuropean and pan-South Asian experiencer-as-goal construction. In this constructional type, the experiencer NP appears in a goal-marking case, which corresponds in Belhare to the zero-marked absolutive (31a). The construction contrasts with experience expressions in the regular transitive scheme, as in (31b):
a. han
ina
lim-yu
$i ?$
2SG[ABS] beer[ABS] [3SG:S-]be(come).tasty-NON.PAST Q
'Do you like the beer?' (lit., 'is the beer tasty to you?'; cf. Nep. timılāı jā d mitho lāgyo?, Germ. Schmeckt dir das Bier?, Russ. Pivo nravitsja tebe? or Span. ¿Te gusta la cerveza?)
b. han-na tombhira kii?-t-u-ga
2SG-ERG lynx[ABS] fear-NON.PAST-3[SG]UND-2[SG:A] Q
'Are you afraid of the lynx?'

The experiencer, not the stimulus, qualifies in Belhare as the subject, following the universal Thematic Hierarchy (as proposed by, e.g. Foley and Van Valin 1984; Givón 1984; Bresnan and Kanerva 1989). It is immaterial for this whether the experiencer is in the absolutive (31a) or in the ergative (31b) case. Therefore, both absolutive and ergative experiencers can be relativized on in a participial relative clause $(32 a, b)$, a construction that is restricted to subjects (defined as the set of $S$ 'single intransitive arguments' and A 'transitive actors'), as shown by (32c-e) (cf. Bickel, in press, for further discussion): 

a. ina
ka-lim-ba
$m a^{2} i$
beer[ABS] ACT.PART-be(come).delicious-MASC person[SG:ABS] 'the man who likes the beer'
$\begin{array}{ll}\text { b. } & \text { tombhira ka-kit-pa } \quad m a{ }^{2} i \\ \text { lynx[SG:ABS] ACT.PART-fear-MASC person[SG:ABS] }\end{array}$
(A-Experiencer, ABS)
'the man who is afraid of the lynx' (A-Experiencer, ERG)
$\begin{array}{lll}\text { c. } & \text { dhol } k a-t e n-b a & a^{2} i \\ \text { drum[ABS] ACT.PART-beat-MASC person[SG:ABS] }\end{array}$
'the man who beats the drum' (A-Agent, ERG)
d. *ka-ten-ba dhol
ACT.PART-beat-MASC drum[ABS]
'the drum that [one] beats' (UND-Patient, ABS)
e. asenle ka-pikga-ba ma?i
lately ACT.PART-fall.down-MASC person[SG:ABS]
'the man who fell down lately'
(s-Theme, ABS)

Thus, the constraint on participial relativization is exclusively sensitive to information from thematic roles on the verb level (i.e. to what Goldberg 1995 calls participant roles); clause-level case-marking on NPs (which corresponds to Goldberg's argument role) is irrelevant. In Lai Chin too, constraints involving grammatical relations are not sensitive to NP-marking and are mapped directly from the semantic structure of the verb. Like Belhare, Lai Chin has a relative construction that is restricted to subjects (Lehmann 1997; Peterson 1998; Kathol and Van-Bik 1999; Bickel 1999b). Whether an experiencer is coded as a possessor as in the psycho-collocations discussed above or whether it is coded as a regular ergative argument is again irrelevant.

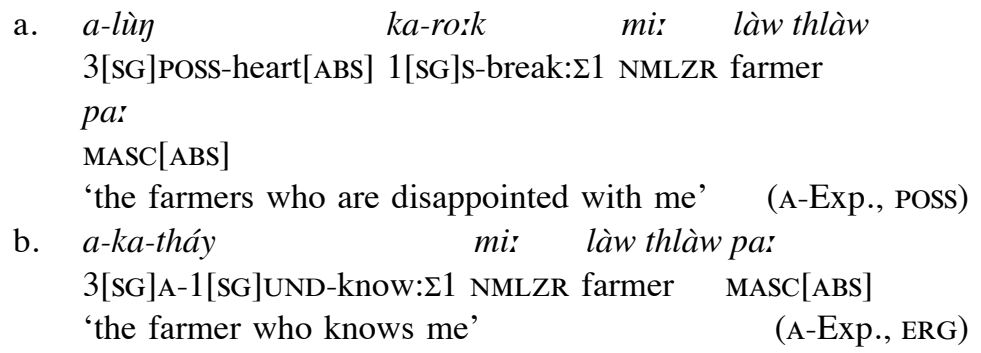

This is in stark contrast with Indo-European languages where grammatical relations not only rely on the hierarchy of verb-level thematic roles, but are 
usually at the same time sensitive to the case-marking on NPs. In both German (34) and Marathi (35) (Indo-Aryan; Pandharipande 1990), for instance, experiencers qualify as subjects only if they are in the nominative. If they are in the dative as in experiencer-as-goal constructions, they typically fail to qualify as subjects (Bickel 1999b):
a. Dem
Lehrer
ART:MASC:SG:DAT teacher(MASC):SG:DAT
schmeck- $t$
Bier.
be.tasty-3SG:NON.PAST beer(NEUT):SG:NOM
'The teacher likes beer.'
b. *der
Bier
ART:MASC:SG:NOM beer(NEUT):SG:NOM
schmeck-end-e
Lehrer
be.tasty-ACT.PART-MASC:SG:NOM teacher(MASC):SG:NOM
'the teacher who likes beer'
a. mulgl-lā
$s \bar{a} d \imath$
āvad-te.
girl(FEM)-SG:DAT saree(FEM):SG:NOM like-SG:FEM:NON.PAST
'The girl likes the saree.'
b. *sādl āvad-nār
saree(FEM):SG:NOM please-ACT.PART:FEM:SG:NOM
mulgl
girl(FEM):SG:NOM
'the girl who likes the saree'

Thus, there appears to be a systematic typological distinction between Tibeto-Burman and Indo-European languages, and this distinction follows from different design principles in the syntax-semantics interface: the associative type of interface found in Tibeto-Burman implies that grammatical relations do not integrate clause-level information. Grammatical relations in languages with integrative interfaces as common in Indo-European, by contrast, are necessarily sensitive to clause-level information and cannot be reduced therefore to verb-level participant roles in Goldberg's (1995) sense.

On the level of discourse, finally, the associative grammar design is manifested in Tibeto-Burman by the ease in which argumental NPs can be dislocated from the verb to which they semantically belong. It is not uncommon in these languages to find structures like the following (Belhare examples): 
a. i-gira hott-he-ga male

one-NON.HUM[ABS] take.out-PAST[3SG:UND]-2[SG:A] not

i? han-na i-gira

Q 2SG-ERG one-NON.HUM[ABS]

$\langle$ V5:25bis $\rangle$

'You took one out, didn't you? You - one?'

b. "abo yeti n-ni-at-ni- $\eta$ ?"

now what[ABS] NEG-See-PAST-NEG[3SG:UND]-1SG:A

=bu lur-he, raja-a khehunna

=REP [3SG:A-]tell-PAST[3SG:UND] king-ERG like.this

bahuni-na

$\langle\mathrm{KP} 30 \mathrm{~b}\rangle$

Brahmin(FEM)[ABS]-TOP

" "Now what didn't I see?" said the king to the Brahmin's wife.' (literally, ' $\ldots$ he said, the king to the Brahmin's wife')

This is in line with a general discourse tendency to avoid clauses with overt NPs. In a narrative production experiment (Bickel 1999d), Belhare speakers produced on the average about $61 \%$ clauses with one or more overt NP, a figure which is significantly lower than the $69 \%$ and $77 \%$ that were characteristic of, respectively, Nepali and Maithili (also cf. Genetti and Crain, in press), Indo-European languages with integrative agreement (see above, Section 3) but otherwise similar syntax.

The associative design of the syntax-semantics interface and the disintegration of NP and verb structure it entails seems to be general even beyond the limits of those Tibeto-Burman languages that feature verb agreement and also manifests itself in Sinitic and Lolo-Burmese languages. Here, the disintegration between NPs and verbs is achieved through what has been called 'topic-prominence' since Li and Thompson's (1976) seminal contribution. A recent study by Tao (1996) shows that only about half of Mandarin Chinese intonation units consist of verb-headed clauses. A substantial proportion (28.7\%) of the rest are made up by bare NPs with various discourse-pragmatic functions, topics among them. (The remainder draws on adverbials and particles.) Thus, Mandarin appears to follow the principle of associative grammar by means of intonation, which tends to separate the verb-headed clausal core from NPs. It is likely that other Sinitic and LoloBurmese languages are similar in this regard, and this would suggest that an associative design of the syntax-semantics interface is indeed a general characteristic of Sino-Tibetan syntax. From such a perspective, associative verb agreement and topic-prominence are complementary reflexes of one and 
the same general design principle in the syntax-semantics interface. This explains why those languages that make most use of verb agreement, such as Kiranti languages, do not generally employ Chinese-style topic constructions (Bickel 1993, 1999a), and why those languages that rely heavily on topic constructions, such as Sinitic and Lolo-Burmese languages (Li and Thompson 1976), lack verb agreement.

\section{Conclusions}

The principle of an associative type of syntax-semantics interface that underlies agreement in languages such as Belhare or Lai Chin imposes a strict distinction between NP and verb structure: features of NPs are established independently of those marked by the conjugational system; the two sets of features are combined through a complex mechanism that allows several types of agreement relations, each with different semantic entailments. This contrasts with agreement in languages with an integrative syntax-semantics interface where the features of NPs and verbal forms systematically merge into a unitary referential expression.

As suggested in Section 4, the principle of associative grammar holds generally for Sino-Tibetan languages and can manifest itself not only through agreement systems but also through a topic-prominent sentential syntax that tends to separate the nominal from the verbal domain by intonational phrasing. There is evidence, discussed in Bickel (1999b, c), that the difference between integrative and associative types of syntax-semantics interfaces is genetically stable to a remarkable degree and that it manifests itself in genetically related languages even when they are typologically extremely diverse in terms of word order, case alignment and other morphosyntactic parameters. From this perspective it does not come as a surprise that the similarity in interface principles between Belhare and Lai Chin is in no conflict with the fact that the actual agreement morphologies of these languages are very different from each other, and that there is as yet no conclusive evidence that they derive from a common system - indeed, it is possible that the morphologies evolved through independent but parallel cliticization and grammaticalization of pronominals. ${ }^{8}$ In Belhare, such cliticization appears to have occurred in the domain of predicate nominals, and the resulting agreement system follows exactly the same principles as verb 
agreement. The following examples illustrate identificational (37a), appositional (37b), and partitional (37c) agreement in nominal sentences:

a. $\eta k a \quad n$-tak- $\eta a$.

1SG:ABS 2SG:POss-friend-[1SG]EXCL

'I am your friend.'

b. m-phay

u-cha

2SG:POss-father's.younger.brother[SG:ABS] 3sG:POSS-child[SG:ABS]

n-nucha-ya.

2SG:POss-younger.patrilineal.relative-[1SG]EXCL

'As your father's younger brother's son, I am your clan brother.' (i.e., 'As your paternal uncle's son, I belong to the same patrilineage as you.')

c. i-bay cor-chi-ga.

one-HUM[SG:ABS] thief-NON.SG-2

'One of you is a thief.'

Whatever individual diachronic developments led to agreement morphology in the nominal and verbal domain, the principle of associative syntax is the same throughout.

Author's Address:

Balthasar Bickel

Department of Slavic Languages

6303 Dwinelle Hall

University of California

Berkeley, CA 94720-2979

email: bickel@socrates.berkeley.edu

http://socrates.berkeley.edu/ bickel

\section{ACKNOWLEDGMENTS}

I am greatly indebted to Lekhbahadur Ra1 and Kenneth Van-Bik for sharing with me their native speakers intuitions about Belhare and Lai Chin, respectively. For help with Spanish data, thanks go to Fernando Zúñiga. My research was supported by the Swiss National Science Foundation, Grant No. 8210-053455. Versions of this paper were presented at the 9th Annual Meeting of the South East Asia Linguistics Society, Berkeley, May 21-23, 1999, at the 5th Himalayan Languages Symposium, Kathmandu, September 13-15, 1999, and in a seminar at 
LaTrobe University, Melbourne, November 18, 1999. For helpful comments on an earlier draft, many thanks go to Johanna Nichols and Kenneth Van-Bik. I am of course alone responsible for all remaining errors.

\section{NOTES}

1. The conjugational morphology of Belhare is discussed in Bickel $(1995,1996)$. Note that in the practical orthography $\langle\mathrm{c}\rangle$ represents /ts/ and that automatic word-initial glottal stop is not written. The following abbreviations are used in examples: A 'actor, most agentive argument of transitive verb', ABL 'ablative', ACT 'active', AFF 'affected object', ART 'article', CAUS 'causative', CLASS '(default) classifier', DAT 'dative', DEF 'definitive future', DEM 'demonstrative', DIM 'diminutive', DIR 'directional case', DIST 'distal', EMPH 'emphatic', ERG 'ergative', EXCL 'exclusive', FEM 'feminine', HUM 'human (classifier)', IMP 'imperative', INCL 'inclusive', INTERJ 'interjection', LOC 'locative', MASC 'masculine', MID.HON 'mid-honorific', NEG 'negative', NON.HON 'non-honorific', NON.HUM 'nonhuman', NON.NOM 'non-nominative', NOM 'nominative', NON.SG 'non-singular', NMLZR 'nominalizer', OPT 'optative', PART 'participle', PL 'plural', POSS 'possessive', PROX 'proximal', Q 'interrogative', $\mathrm{s}$ 'single argument of intransitive verb', SEQ 'sequential', SG 'singular', TEMP 'temporary (aspect)', TOP 'topic', UND 'undergoer, most patientive argument of transitive verb', $\Sigma$ 'stem form (in Chin)'. '>' marks a transitive relation, '=' signals a clitic boundary. Elements in square brackets are entailed by paradigm structure or obligatory opposition without being overtly marked (i.e. zero-marked).

2. Lai Chin morphology is discussed by Kavitskaya (1997) and Peterson (1998). Note that the standard Roman orthography of Lai Chin suggests that what I analyze here as agreement markers are independent pronouns. However, as demonstrated by Bedell (1995), this is at variance with their grammatical properties, and I adopt here an orthography that reflects this. In line with common practice in South-East Asian linguistics, I use spaces to demarcate prosodic rather than morphosyntactic words (which often comprise long series of prosodic words). As in Belhare (see Note 1), glottal stop is automatic in vowel-initial words and is not written here.

3. A literal translation of (10a) into German brings this structure to the fore: Sie machen mir mein Herz grün 'they make my heart green for/on me', where the first person pronoun mir in the dative marks the possessor as an affected participant.

4. See Shibatani (1994) for a general theory of such extra-thematic arguments.

5. Thus, a closer translation of (22a) is German Er rennt dir davon 'he rans away on you', with the second person pronoun dir in the dative representing an affected additional argument.

6. For the concept of head-marking, see Nichols (1992). Belhare and Lai-Chin are double-marking languages with both case and agreement systems signaling argument roles.

7. Double-marking languages of Australia too seem to defy an analysis in terms of argument absorption by agreement; see Simpson (1991), Austin \& Bresnan (1996), and Nordlinger (1998) for extensive argumentation. 
8. See Nishi (1995) for a recent review of the current debate about the reconstructability of verb agreement in Tibeto-Burman.

\section{REFERENCES}

Austin, Peter; and Bresnan, Joan, 1996. "Non-configurationality in Australian Aboriginal languages". Natural Language and Linguistic Theory 14: 215-68. Baker, Mark C. 1996. The polysynthesis parameter. New York: OUP.

Bally, Charles, 1926. "L'expression des idées de sphère personelle et de solidarité dans les langues indo-européennes". In: Frankhauser, F.; and Jud, J. (eds), Festschrift Louis Gauchat 68-78. Aarau: Sauerländer.

Bedell, George, 1995. "Agreement in Lai". In: Chelliah, Shobhana L.; and Reuse, Willem J. de (eds), Papers from the 5th Annual Meeting of the South-East Asian Linguistics Society. Tempe, AZ: Program for Southeast Asian Studies, Arizona State University.

Bickel, Balthasar, 1993. "Belhare subordination and the theory of topic". In: Ebert, Karen H. (ed.), Studies in clause linkage 23-55. Zürich: ASAS Press. Bickel, Balthasar, 1995. "In the vestibule of meaning: Transitivity inversion as a morphological phenomenon". Studies in Language 19: 73-127.

Bickel, Balthasar, 1996. Aspect, mood, and time in Belhare.Zürich: ASAS Press. Bickel, Balthasar, 1999a. "From ergativus absolutus to topic marking in Kiranti: A typological perspective". Proceedings of the 25th Annual Meeting of the Berkeley Linguistics Society 38-49.

Bickel, Balthasar, 1999b. "Grammatical relations, agreement, and genetic stability". Ms., University of California at Berkeley [http:// socrates.berkeley.edu/ bickel/papers].

Bickel, Balthasar, 1999c. "Principles of event framing: genetic stability in grammar and discourse". Ms., University of California at Berkeley, [http://socrates.berkeley.edu/ bickel/papers.]

Bickel, Balthasar, 1999d. "How important are referents? Syntactic typology and cognitive effects". Paper presented at the workshop on Event Conceptualization, Max Planck Institute for Psycholinguistics, Nijmegen, December 17-19, and at the Cognitive Typology Conference, Antwerpen, April 12-14, 2000 [Ms. available at http://socrates.berkeley.edu/ bickel/ papers]. 
Bickel, Balthasar, in press. "Hidden syntax in Belhare". In: Driem, George van (ed.), Himalayan Linguistics. Berlin: Mouton de Gruyter.

Bickel, Balthasar; Bisang, Walter; and Yadava, Yogendra P. 1999. "Face vs. empathy: The social foundations of Maithili verb agreement". Linguistics 37: 481-518.

Bresnan, Joan; and Kanerva, Jonni, 1989. "Locative inversion in Chichewa: A case study in factorization in grammar." Linguistic Inquiry 20: 1-50.

Bresnan, Joan; and Mchombo, Sam A. 1987. "Topic, pronoun, and agreement in Chichewa". Language 63: 741-82.

Chung, Sandra, 1998. The design of agreement: Evidence from Chamorro. Chicago: The University of Chicago Press.

Corbett, Greville G. 1983. Hierarchies, targets, and controllers: Agreement patterns in Slavic. University Park: The Pennsylvania State University Press.

Driem, George van, 1991. "Tangut verbal agreement and the patient category in Tibeto-Burman". Bulletin of the School of Oriental and Asian Studies 54: 520-34.

DuPonceau, Peter S. (1819). "Report of the Corresponding Secretary to the Committee, of his progress in the investigation committed to him of the general character and forms of the languages of the American Indians". Transactions of the Historical and Literary Committee of the American Philosophical Society 1: xvii-xlvi

Foley, William A.; and Van Valin, Jr., Robert D. 1984. Functional syntax and universal grammar. Cambridge: CUP.

Genetti, Carol; and Crain, Laura D. In press. "Beyond preferred argument structure: Sentences, pronouns and given referents in Nepali”. In: Ashby, William, DuBois, John W.; and Kumpf, Lorraine (eds), Preferred argument structure. Amsterdam: John Benjamins.

Givón, T. 1984. Syntax: A functional-typological introduction, Vol. I. Amsterdam: John Benjamins.

Goldberg, Adele, 1995. Constructions: A construction grammar approach to argument structure. Chicago: The University of Chicago Press.

Hale, Kenneth, 1983. "Warlpiri and the grammar of nonconfigurational languages". Natural Language and Linguistic Theory 1: 5-47.

Humboldt, Wilhelm von, 1836. Über die Verschiedenheit des menschlichen Sprachbaus und ihren Einfluss auf die geistige Entwickelung des Menschengeschlechtes. Berlin: Dümmler. 
Jelinek, Eloise, 1984. "Empty categories, case, and configurationality". Natural Language and Linguistic Theory 2: 39-76.

Kathol, Andreas; and Van-Bik, Kenneth, 1999. "Morphology-syntax interface in Lai internally-headed relative clauses". Proceedings of the 29th Meeting of the North-Eastern Linguistics Society 427-41.

Kavitskaya, Darya, 1997. "Tense and aspect in Lai". Linguistics of the Tibeto-Burman Area 20(2): 173-213.

König, Ekkehard; and Haspelmath, Martin, 1998. "Les constructions à possesseur externe dans les langues de l'Europe". In: Feuillet, Jack (ed.), Actance et valence dans les langues de l'Europe 525-606. Berlin: Mouton de Gruyter.

Lehmann, F. K. 1997. "Relative clauses in Lai, with special reference to verb stem alternations and the extension of control theory". Linguistics of the Tibeto-Burman Area 19(1): 43-58.

Li, Charles N.; and Thompson, Sandra A. 1976. "Subject and topic: A new typology of language”. In: Li, Charles N. (ed.), Subject and topic 459-89. New York: Academic Press.

Matisoff, James A. 1986. "Hearts and minds in South-East Asian languages and English: An essay in the comparative lexical semantics of psychocollocations". Cahiers de linguistique asie-orientale 15: 5-57.

Matisoff, James A. 1991. "Sino-Tibetan linguistics: Present state and future prospects”. Annual Review of Anthropology 20: 469-504.

Mithun, Marianne, 1985. "Disagreement: The case of pronominal affixes and nouns". Georgetown University Round Table on Language and Linguistics 1985: 50-66.

Nichols, Johanna, 1992. Language diversity in space and time. Chicago: The University of Chicago Press.

Nishi, Yoshio, 1995. "A brief survey of the controversy in verb pronominalization in Tibeto-Burman”. In: Nishi, Yoshio; Matisoff, James A.; and Nagano, Yasuhiko (eds), New horizons in Tibeto-Burman morphosyntax 1-16. Osaka: National Museum of Ethnology.

Nordlinger, Rachel, 1998. Constructive case: Evidence from Australian languages. Stanford: CSLI.

Pandharipande, Rajeshwari, 1990. "Experiencer (dative) NPs in Marathi”. In: Verma, Manindra K.; and Mohanan, K.P. (eds), Experiencer subjects in South Asian languages 161-79. Stanford: CSLI. 
Payne, Doris L.; and Immanuel Barshi (eds). 2000. External Possession. Amsterdam: John Benjamins.

Pensalfini, Robert. In press. "Towards a typology of nonconfigurationality".

Natural Language and Linguistic Theory.

Peterson, David A. 1998. "The morphosyntax of transitivization in Lai (Haka Chin)". Linguistics of the Tibeto-Burman Area 21: 87-153.

Shibatani, Masayoshi, 1994. "An integrational approach to possessor raising, ethical datives and adversative passives". Proceedings of the 20th Annual Meeting of the Berkeley Linguistics Society 461-86.

Simpson, Jane, 1991. Warlpiri morpho-syntax: A lexicalist approach. Dordrecht: Kluwer.

Tao, Hongyin, 1996. Units in Mandarin conversation. Amsterdam: John Benjamins.

Van Valin, Jr., Robert D. 1985. "Case marking and the structure of the Lakhota clause". In: Nichols, Johanna; and Woodbury, Anthony C. (eds), Grammar inside and outside the clause 363-413. Cambridge: CUP.

Van-Bik, Kenneth, 1998. "Lai psycho-collocations". Linguistics of the TibetoBurman Area 21(1): 201-33.

Van-Bik, Kenneth, 1999. "Causatives in Lai". Paper presented at the 9th Annual Meeting of the South East Asia Linguistics Society, Berkeley, 21-23 May.

Yadava, Yogendra P. 1996. "Verb agreement in Maithili". Journal of Nepalese Studies 1: 109-21. 